\title{
VERBAL TAXONOMIC MODEL OF THE VISUAL PERCEPTION CONCEPT BASIC LEVEL
}

\author{
Karabayeva Barno \\ Senior Scientific researcher at \\ Uzbekistan State World Languages University \\ E-mail: girl_1612@mail.ru
}

\begin{abstract}
In this article the suggestion that English verbs with the meaning of "visual perception", which unites them, may be presented in the form of the verbal taxonomic model is given. The aim of the work is the creation of the taxonomic model of the "visual perception" concept, defining its structure, categories, and the studying of the semantics of the verbs of visual perception for the level classification of them.
\end{abstract}

Key words: visual perception, verbal taxonomy, basic, subordinate, tier, hierarchy, morphological, frequent, transitory, etymology.

The abstract of the article lies in creating the verbal taxonomic model of the visual perception, defining the structure, categories of the model, and studying the semantics of the verbs of visual perception for the level classification of them.

The topicality of the article involves the creating the taxonomic model of the visual perception verbs which allows to develop the concept itself. Moreover, the verbs are separated into levels by their specific features.

Taxonomic concept modeling of visual perception involves primarily the consideration of the perceptual activity nature, its representation, as an active and targeted process (In this case the aim is to obtain a definite visual image) on one hand and on the other hand, as undirected and unconscious passive vision, expressed only in fixing the visual images received from 
certain stimulus, and their primary treatment. In the hierarchy of characteristics of the visual perception concept, the distinction of the given two types of visual perception is reflected in the profiling or non-profiling of characteristics of "direction" in the conceptual structure of the represented verbs of visual perception. In this hierarchy of language, verbal taxonomic model, which correlated with it, this essential feature of perceptual events is presented in the appropriate language semantic units that represent two opposed categories of activeness/inactiveness in English. These linguistic units, first of all, the verbs to see / to look represent perceptual process in the form of gestalt, i.e. without specifying its individual characteristics, and being dominant or categorical identifiers in relation to other elements of the taxonomy, to the verbs with specific meaning.

The main levels of the studied verbal taxonomy are considered to be two levels of categorization - basic and subordinate. Basic and subordinate levels can be represented in the form of hierarchically positioned tiers. Meanwhile, in the basic level the selection of the two tiers is justified, but in the subordinate level there are three tiers, the elements of which will vary in the the degree of implementation of the basic level criteria. (15)

Thus, let us consider the basic level of the taxonomic model of the visual perception concept based on English verbs.

The basic level of the verbal taxonomic model of the visual perception

Basic taxonomic model of visual perception suggests that the conceptualization of perceptual events is carried out with the application of minimal cognitive effort to process visually perceived information. This level does not imply a significant refinement of conceptualization perspective, taking into account the peculiarities of perception. In the hierarchy of conceptual characteristics this level possesses the most important binding conceptual characteristics which transmit knowledge about prototypical situation of visual perception. These characteristics are the characteristics of the "Subject" "Object" and "Direction". In English verbs to see and to look are the main representatives of conceptual characteristics of information. The conceptual characteristic of the "Direction" is profiled in the conceptual structure, which is represented by verb to look. It allows to distinguish two types of perception - purposeful look and unfocused vision which are 
represented by the verb to see. This verb forms the first and the second studied focuses of taxonomic model, as well as its basic level.

English verbs to see and to look form the first tier of the basic level. In the conceptual framework, which is represented by these verbs in their basic meaning, only conceptual baseline characteristics are profiled. Verbs to see, to look transmit two types of visual perception without specifying its individual aspects. This is indicated by the dictionary definitions of the verbs: to see "have or use the power of sight», to look - «to turn your eyes towards something, so that you can see it».

Another criterion, which affirms the basic nature of the verbs to see and to look in the taxonomy structure is their morphological simplicity. Verbs to see and to look are monosyllabic. These verbs are able to form prepositional, phrasal and phrasal-prepositional expressions. However, unlike the verb to look, the verb to see does not attach object using a preposition at or on because it is a transitory verb, and it represents the process of visual perception as inactive and non-directional. In general, in combination with prepositions of direction verb to see often acts as part of the transitory phrasal verbs which indicates a change in categorical status of the verb and reflects the functional aspect of categorization (example (4)):

1. His wife looks at me archly from beneath her plucked eyebrows (Harris

2011: 244);

2. < ..> when I finally looked back, he had gone (Harris 2011: 276);

3 . They were the crowd whose heads you could not see over;

4. Haven't seen you around. - (22);

However, it should be noted that in combination with inanimate and abstract nouns verbs to see and to look are exposed to metaphorization, which is quite logical according to the fact that only living beings are able to see and to watch.

With regard to the frequency of use, the verbs to see and to look are the most frequent verbs of visual perception in English. However, in the English the verb to look has smaller frequency comparing with the verb to see. Thus, the results of research carried out on the basis of the Oxford English Corpus data, indicate that the verb to look occupies position 74 of the 100, while to see - 69. In its turn, the verb to look takes $13^{\text {th }}$ position among the most frequent 
verbs, and the verb to see $-10^{\text {th }}$. As for the French verbs, then, being most frequency French verbs of visual perception, to statistical scale they, nevertheless, are far removed from each other.

Verbs to see and to look are stylistically neutral. (10)

The second tier of the basic level in the studied taxonomy model according to N. N. Boldyrev, can be called "Transitory" or "Transitory zone". According to N. N. Boldyrev, "transitory zone" reflects different methods of discretisation of the semantic continuum in the language: "Despite the fact that the linguistic signs are assigned to various parts of the semantic continuum, and it has a relatively fixed nature, boundaries between them are not strict, i.e. they have the character transition zone "[Boldyrev, 1994: 145; 1995a: 91]. By "transition zone" of the taxonomic model of the concept within this paper we will consider a definite taxonomy tier in which the verbs of visual perception which meet the criteria of basic level and criteria of subordinate level. The conceptual content, which is represented by the verbs of "transition zones" of visual perception taxonomy, on the one hand, does not allow us to talk about gestalt perception, and on the other - a significant concretization of this conceptual content, as well as the existence of ties in interconceptual framework, represented by a verb. Thus, in the conceptual hierarchy of the characteristics of the basic level, the second tier is presented by one (or two, but "conceptually related") additional characteristic(s) of the concept of visual perception, along with binding characteristics, "subject", "object" and "direction". These characteristics are profiled in the conceptual structure which is represented by the verbs of visual perception which meet almost all basic level criteria. The lack of any following criteria is considered as an indicator of the border ("transitory") position of these verbs between the two levels.

The second ("transitory") tier of the basic level of the verbal taxonomy model in English includes the verbs to watch, to stare and to gaze. Verbs to watch, to stare and to gaze represent perceptual situation not in gestalt way, in the conceptual structure of the event which is presented by these verbs the additional conceptual characteristic of "Time" is profiled more (or "Time" ("Duration")) and also related characteristic of "Image" ("Method").

Let us consider these verbs. 
The main meaning of the verb to watch: «to look at someone or something for a period of time, paying attention to what is happening». The dictionary definition indicates that the verb to watch represents the process of visual perception not in gestalt way because in the conceptual structure which is represented by this verb, along with the conceptual characteristics of the basic level, the additional characteristics of "Time" (for a period of time) and "image" ("Method") (paying attention to what is happening) are profiled. The verb to watch is monosyllabic and it is able to form prepositional phrases, phrasal and prepositional-phrasal expressions. For example:

5. This morning I unmade the window display, the witch, the gingerbread house and all the chocolate animals sitting around watching with glossy expectant faces <...> (Harris 2011: 168);

6. "Watch out for crocodiles", I told her seriously (Harris 2011: 334).

The verb to watch also has a broad combinability and may be used with different types of subjects:

7. Jeannot Drou watched me in the kitchen, a piece of gilded pain pieces in

each hand, eyes shining (J. Harris 2011: 334) (animate subject);

8. But Shand is less sympathetic than Cutter, his rage has a dubious moral basis and the film is filled with venom and relish as it [the film] watches empires collapse (inanimate subject).

There is no stylistic coloration in the definitions of the verb to watch, i. e. this verb can be used in different contexts. The etymological analysis showed that the verb to watch has Germanic origin and it is a native English verb. Note that, despite the fact that both the verb to watch and the verb to see were registered in year of 725 in Beowulf, only the verb to see directly transmitted the visual perception process, namely, purposeful process of visual perception.

The verb to watch, along with the verbs to look and to see, is one of the most frequently used verbs of visual perception, which is also confirmed by different sources. Thus, the Longman Dictionary researchers created the graph of frequency. Despite the fact that the verbs to see and to look have significantly larger frequency in comparison with the verb to watch in speaking and writing of the English speakers, the verb to watch is the third 
frequent verb visual perception. This preponderance of the colloquial use is obvious. (19)

Let us now consider the verb to stare. The verb to stare fails to observe a gestalt criterion which is expressed in the fact that it transfers the process of visual perception with the clarification of the special perceptual aspects of the situation: «to look at somebody / something for a long time». This definition indicates that the conceptual structure which is represented by the verb to stare, possesses conceptual description of "Time" ("Duration") (for a long time) more than others. The characteristic of "Image" ("Method") which usually accompanies "Time" in this case is not profiled, which is expressed by the definition provided. Nevertheless, you can find an example of the definition which indicates the profiling and refinement of the characteristics in the conceptual structure of the represented verb to stare: to look fixedly often with wide-open eyes. The verb to stare is monosyllabic. The verb is often used with prepositions and postverbs:

9. "You were going seventy in a fifty-mile zone", - he said, staring coldly at Thomas (32);

10. As his National Security Assistant moved to the telephone, the President stared moodily out of the window (24).

The verb to stare may be used with different types of subjects:

11. "I I'll take my oath and put it down on that chair", said George, staring at the empty seat (29) (animate subject);

12. A thousand windows, some reflecting the dying light of the day, stared down with him at the trampled earth (31)(inanimate subject);

13. Hunger stared down from the smokeless chimneys, and started up from the filthy street that had no offal, among its refuse, of anything to eat (abstract subject).

The verb to stare is used in a variety of contexts, being stylistically neutral. The etymology of the verb to stare indicates that it has Germanic origin and it is a native English verb. The high frequency of use of the verb to stare is another proof of its membership in the basic level. For example, in the dictionary of the most common words of English by Vasiliev verb to stare is the most common verb of visual perception verb after verb to see, to look and to watch, taking up a position number 176 with a frequency of use of 19.238. 
The verb to gaze has the main meaning: «to look at someone or something for a long time, giving it all your attention, often without realizing you are doing so». This definition points to the failure of the verb to observe the criterion of gestalt process of visual perception. Thus, the meaning of the verb to gaze is transferred through the verb to look of the first tier of the basic level. The definition of the verb allows to consider the profiling of additional conceptual characteristic of the "Time" ("Duration") (for a long time) and related to it "Image" ("Method") (giving it all your attention). The verb to gaze is monosyllabic and it is used with postverbs:

14. Then, in the sorrowful moments of our triumphant power, their eyes gaze on us with a mute reproach (Gaskell 1956: 209);

15. She sat on the high, steel stool in front of the moviola, pushing the levers, gazing intently into the glass screen (Shaw 2008: 548). 74

The verb to gaze may be used with different types of subjects:

16. The thirty-four-year-old initiate [a man who undertook ritual] gazed down at the human skull cradled in his palms (Brown 2010: 3) (animate subject);

17. And if you gaze long into an abyss, the abyss will gaze back into you (Quote by Friedrich Nietzsche) (the abyss - inanimate subject).

The verb to gaze is used in a variety of contexts, as stylistically neutral verb. The etymology of the verb to gaze indicates that it has a Scandinavian origin, i.e., it is not English native. However, this derogation from the main requirements of the basic level is only a consequence and confirmation of the transitional nature of the verb and it does not contrast its assignment to the second tier of the basic level. In addition, the frequency of use of the verb to gaze also proves that it belongs to the basic level. In the dictionary of Vasiliev it takes the position 835 among all analyzed words (of 2500 products) with the frequency of occurrence of 3.343 , while the verb is mentioned after the verb to stare.

Verbal taxonomic model of visual perception consists of two levels, basic and subordinate. Basic level includes two tiers. The first tier of the basic level presents the dominant group of visual perception verbs (to see / to look). The second tier of the basic model is the "transitory" tier, which combines verbs of visual perception, represents a conceptual structure in which one or two (but interrelated) conceptual characteristics are profiled, 
while all other basic criteria are met. To say briefly about the subordinate level, it may be divided into three tiers. The first tier of the subordinate level is "transient" because this level consists of verbs of visual perception, which represent the visual perception only in its prototypical form without transmitting other events, however, providing for definite specification and conceptualization of perceptual events. The second tier subordinate level is represented by verbs, etymologically belonging to other lexical categories, as well as verbs, which in their main meaning are able to represent particular features of both perceptual and other events at the same time. The third tier consists of verbs that are mainly do not represent the process of visual perception, however, at the level of the context these verbs can implement perceptual importance. 


\section{References:}

1. Арутюнова Н.Д. Типы языковых значений. Оценка. Событие. Факт. - М.: Наука, 1988. - 339 с.

2. Архипова Ю.Ю. Состав, семантика и функционирование лексико-семантической группы глаголов зрительного восприятия (на материале художественный текстов) Дисс. ... канд. филолог. наук. С.Петербург, 2000. - 197 с.

3. Болдырев Н.Н. Функциональная аналогия в субъектнопредикатинвых отношениях на разных уровнях построения // Функциональные типы и функциональные модификации языковых единиц. - Л.: ЛГПИ им. А.И. Герцена, 1983. - С. 29 -36.

4. Болдырев Н.Н. Категориальное значение глагола: системный и функциональный аспекты. - С.-Петербург: РГПУ, 1994. - 171 с.

5. Болдырев Н.Н. Функциональная категоризация английского глагола: монография. - С.-Петербург. - Тамбов: РГПУ/ТГУ, 1995. - 139 с.

6. Болдырев Н.Н. Функциональная категоризация английского глагола. Дисс. ... докт. филолог. наук. СПб., 1995а. - 445 с.

7. Болдырев Н.Н. Функциональная категоризация глагола и динамика глагольного значения // Языковая категоризация (части речи, словообразование, теория номинации): Материалы Круглого стола, посвящѐнного юбилею Е. С. Кубряковой. - М.: ИЯз Ран, 1997. - 96 c.

8. Будагов Р.А. Сравнительно-семасиологические исследования. Романские языки. - М.: Изд-во МГУ, 1963. - 301 с.

9. Волкова Н.В. Метафорика переносного значения английских глаголов видения. Автореф. дисс. ...канд. филолог. наук. Уфа, 2009. - 24 c.

10. Грегори Р.Л. Глаз и мозг: психология зрительного восприятия. - М.: Прогресс, 1970. - 270 с.

11. Демидов В.Е. Как мы видим то, что видим. - Москва: Знание, 1979. - 208 c.

12. Кобрина Н.А. Функциональная модель языка // Взаимодействие языковых единиц различных уровней. - Л.: Изд-во ЛГПИ, 1981. - С. 30-45. 
13. Колесов И.Ю. К вопросу о лингвистике видения и видимого // Международный конгресс по когнитивной лингвистике: сб. ст. Тамбов: Издательский дом ТГУ им. Г. Р. Державина, 2008. - С. 71-74.

14. Крючкова Т.В. Функциональная категоризация глаголов и устойчивых глагольных словосочетаний со значением слуховой перцепции в современном английском языке. Дисс. ...канд. филолог. наук. Белгород, 2004. - 157 с.

15. Куксова Н.А. Глагол как средство функциональной категоризации пространства в современном английском языке. Дисс. ...канд. филолог. наук. Тамбов, 2006. - 168 с.

16. Лайонз Дж. Введение в теоретическую лингвистику / Пер. с англ. В. А. Звегинцева. - М.: Прогресс, 1978. - 544 с.

17. Лакофф Дж., Джонсон М. Метафоры, которыми мы живем. М.: Издательство ЛКИ, 2008. - 256 с.

18. Малинина С.M. K проблеме семантики глагольных и именных комплексов с постпозитивным элементом // Проблемы семантического описания единиц языка и речи. Тезисы докладов Международной научной конференции. - Минск: МГЛУ 1998. - Ч. II. C. 91-92.

19. Обвинцева Н.В. Глаголы восприятия в составе фразеологизмов // Языки профессиональной коммуникации. Челябинск, 2007. - Т. І. - С. 292-295.

20. Панасенко Л.А. Функциональнаяполикатегоризация глагола в современном английском языке. Дисс. ...канд. филолог. наук. Тамбов, 2000. - 186 c.

21. Уэйншенк С. 100 главных принципов дизайна / как удержать внимание. - СПб.: Питер, 2012. - 272 с.

22. Abrahams P. The Pass of Thunder. - M.: Foreign Languages Publishing House, 1954. - 296 p.

23. Brown D. Lost Symbol. - USA: Anchor Books, 2012. - 671 c.

24. Collins L. and Lapierre D. The Fifth Horseman: Granada Publishing Limited, 1991. - 576 p.

25. Dickens Ch. The Pickwick Papers. - London: Wordsworth classics, 1993. - $743 \mathrm{p}$. 
26. Fauconnier G. Mappings in Thought and Language. - USA: Cambridge University Press, 1999. - 205 p.

27. Gaskell E. Mary Barton. M.: Foreign Languages Publishing House, 1956. -468 c.

28. Harris J. Chocolat. M.: Эксмо, 2011. - 544 p.

29. Jerome K.J. Three Men in a Boat. - M.: Foreign Languages Publishing House, 1948. - 178 c.

30. Langacker R.W. Grammar and Conceptualization. - Berlin, New York: Mouton de Gruyter, 2000. - 427 p.

31. Piaget J. The mechanisms of perception. - N.Y.: Basic Books, 1969. $-284 p$.

32. Shaw I. Rich Man, Poor Man. - С.-П.: Kapo, 2008. - 640 c. 